- FINANSE I PRAWO FINANSOWE.

- Journal of Finance and Financial Law

Czerwiec/June 2017 • vol. 2(14): 41-52

http://dx.doi.org/10.18778/2391-6478.2.14.04

\title{
OCHRONA I PRAWA KLIENTÓW KANAŁU BANCASSURANCE W KONTEKŚCIE UBEZPIECZEŃ NA ŻYCIE
}

Irmina Florek

Wydział Ekonomiczny

Uniwersytet Marii Curie-Skłodowskiej w Lublinie

\begin{abstract}
Streszczenie
Współpraca instytucji bankowych z zakładami ubezpieczeń, zwana bancassurance, wraz z rozwojem odnotowała istotny problem niewłaściwej ochrony klienta w systemie sprzedaży ubezpieczeń. W pracy zostanie ukazana istota bancassurance, znaczenie ubezpieczeń na życie, podstawy prawne regulujące ten kanał oraz ochrona i prawa klientów. Celem pracy jest przedstawienie i ocena regulacji obecnie obowiązujących na polskim rynku, odnoszących się do relacji z klientami kanału bancassurance.
\end{abstract}

Słowa kluczowe: bancassurance, ochrona klienta, ubezpieczenia na życie.

JEL Class: G22, D18. 


\section{WPROWADZENIE}

Zmiany zachodzące $\mathrm{w}$ polskiej gospodarce na przestrzeni lat jak również rosnące wymagania i potrzeby klientów zobligowały instytucje sektora finansowego do wprowadzania nowych rozwiązań oraz regulacji do swojego wachlarza usług. Zjawiskiem, odbiegającym od stricte działalności zarówno rynku bankowego jak i ubezpieczeniowego jest bancassurance, angażujący banki jako kanały dystrybucji produktów zakładów ubezpieczeniowych, w formie współpracy między tymi instytucjami. Wraz z rozwojem tego kanału dystrybucji ubezpieczeń na polskim rynku powstał problem właściwej ochrony klienta. Brak jasno sprecyzowanych przepisów prawnych wywołał wiele nieporozumień i nieprawidłowości, co skutkowało rosnącą liczbą skarg do Rzecznika Ubezpieczonych (od 2015 r. do Rzecznika Finansowego). W pracy przedstawione zostanie pojęcie bancassurance oraz podstawy prawne, regulujące ten kanał dystrybucji. Po zdefiniowaniu bancassurance, ukazana zostanie pozycja klienta oraz jego ochrona pod względem prawnym a także znaczenie ubezpieczeń na życie w systemie bancassurance. Celem niniejszego artykułu jest próba oceny obecnej sytuacji klienta kanału bancassurance oraz znaczenia wprowadzenia Rekomendacji U na rynku bankowo-ubezpieczeniowym.

\section{ISTOTA I CHARAKTER KANAtU BANCASSURANCE}

Zmieniające się otoczenie gospodarki rynkowej oraz rosnąca konkurencja zobligowały sektor finansowy do poszukiwania alternatywnych powiązań i relacji między podmiotami w celu zapewnienia optymalizacji oczekiwanych przychodów oraz stabilizacji pozycji rynkowej. Istotny element działalności zarówno banków jak i zakładów ubezpieczeniowych stanowi pośrednictwo finansowe, jednak instytucje te stosują rozbieżne modele finansowe. Rynek finansowy wykreował wiele powiązań pomiędzy instytucjami bankowymi i ubezpieczeniowymi. Mówiąc o współpracy pomiędzy tymi podmiotami najczęściej używa się terminu bancassurance, definiowanego jako kooperacja bankowo-ubezpieczeniowa $\mathrm{w}$ systemie tworzenia wartości rynkowej [Handschke i Monkiewicz 2010: 348]. Bancassurance wchodzi w skład szeroko rozumianego Allfinanz, którego terminologia określa jako integrację kanałów dystrybucji różnych usług finansowych [Śliperski 2002: 21]. Graficznie Allfinanz, jako system powiązań przedstawia rysunek 1 . 


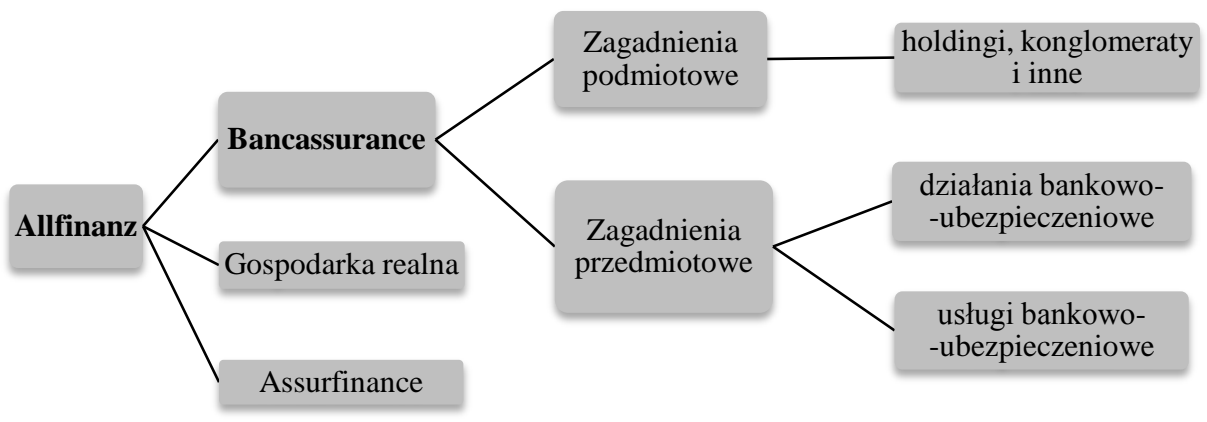

Rysunek 1. Podział działalności Allfinanz

Źródło: Śliperski [2002: 9].

W szerszym ujęciu, zakres bancassurance ujmuje produkty oraz czynności, umożliwiające klientowi instytucjonalnemu bądź indywidualnemu stworzenie, zagospodarowanie oraz zabezpieczenie swojego majątku, zdrowia lub życia. Możliwe jest zastosowanie trzech modeli organizacyjnych, wykorzystujących banki w dystrybucji produktów ubezpieczeniowych [Korenik 2006: 208]:

- jednostki ubezpieczeniowe, stanowiące własność banków - bank posiada większość udziałów firmy, którą przejął, założył bądź z którą się połączył,

- bankowy captive ubezpieczeniowy - ubezpieczenia firmy, której bank jest właścicielem, oferowane głównie w placówkach bankowych,

- bank występujący w postaci pośrednika ubezpieczeniowego - bank współpracuje z firmami ubezpieczeniowymi jako agent ubezpieczeniowy.

Każda $\mathrm{z}$ form zapewnia w swojej ofercie kompleksowe usługi finansowe, które stanowią podstawową zaletę bancassurance.

Jak wskazują analizy, usługi bankowe i ubezpieczeniowe były łączone od paru wieków. W Belgii, Hiszpanii i Francji, historia banków, oferujących w swoich produktach ubezpieczenia sięga XIX w., jednak dopiero od kilkudziesięciu lat instytucje finansowe dostrzegają korzyści, wynikające ze współpracy rynków bankowych i ubezpieczeniowych. Francuski autor Jean-Pierre Daniel w swoich opracowaniach sformułował fazy rozwoju usługi bancassurance, badania bazowały na rynku francuskim w odniesieniu do krajów europejskich. Autor przedstawił 3 fazy, pierwszym był okres 1980, w którym to banki udzielały gwarancji ubezpieczeniowych, stanowiących bezpośrednie rozszerzenie działalności bankowej. Po 1980 r. na rynku bankowym rozwinęły się produkty oszczędnościowe, związane z ubezpieczeniami na życie, uwzględniające korzyści podatkowe. W latach 90 produkty ubezpieczeniowe dostarczane przez banki 
zostały zdywersyfikowane, nie tylko w kategorii ubezpieczeń na życie ale również o ubezpieczenia powszechne [Genetay i Molyneux 1998: 10, 11].

Wśród korzyści z zastosowania bancassurance dla banków wymienia się [Davis 2007: 12]:

- bezpieczne, dodatkowe i stabilne dochody, uzyskane poprzez dywersyfikację oferowanych produktów oraz zmniejszenie wpływu instytucji, oferujących ubezpieczenia, będące ich głównym źródłem dochodów,

- zwiększenie grona klientów oraz wzrost ich lojalności, dostęp do baz klientów zakładów ubezpieczeniowych,

- możliwość oferowania szerokiego wachlarza usług finansowych,

- usługi dostosowane do cyklu życia klientów,

- banki, jako ubezpieczyciele często mogą korzystać z ulg podatkowych.

Natomiast zaletami zastosowania bancassurance wśród zakładów ubezpieczeniowych są [Davis 2007]:

- dostęp do rozległych baz klientów banków,

- zmniejszenie zależności od tradycyjnych agentów na rzecz różnorodnych kanałów dystrybucyjnych banków,

- zdobycie silnej pozycji na rynku bez obowiązku rozbudowywania sieci agentów ubezpieczeniowych,

- możliwość uzyskania od banku kapitału na poprawę wypłacalności oraz rozwinięcia biznesu.

Kanał bancassurance jako instrument współpracy banków i zakładów ubezpieczeń pozwala na kompleksową usługę sprzedaży produktów bankowych razem z produktami ubezpieczeniowymi, które zapewniają wiele korzyści obu instytucjom. Historia pokazuje, że dopiero w ostatnich latach bancassurance został doceniony pod względem zalet i możliwości jaki niesie za sobą ten instrument.

\section{SYTUACJA BANCASSURANCE W POLSCE. POZYCJA KLIENTA ORAZ PRAWNE ASPEKTY KANAtU}

\subsection{Podstawy prawne bancassurance}

Działalność instytucji bankowych zdeterminowana jest przepisami Prawa Bankowego z dnia 29 sierpnia 1997 r. Zapisy ustawy (artykuł 5) określają konkretne czynności, które banki mogą wykonywać w ramach swojej działalności. Oprócz czynności bankowych, instytucje te moga „świadczyć inne usługi finansowe" o czym mówi artykuł 6 ust. 1 punkt 7 [Ustawa z dnia 29 sierpnia 1997 r. ...]. Do 
takich usług można zaliczyć zawieranie umów ubezpieczeniowych w cudzym imieniu, co stanowi podstawę do wykonywania działalności agencyjnej przez banki w ramach podpisanych umów z zakładami ubezpieczeń.

Bank, występujący w roli pośrednika jako agent ubezpieczeniowy, podlega przepisom ustawy z dnia 22 maja 2003 r. o pośrednictwie ubezpieczeniowym. Artykuł 7 ust. 1 determinuje agenta ubezpieczeniowego jako przedsiębiorcę, który wykonuje działalność agencyjną na podstawie umowy agencyjnej, zawartej z zakładem ubezpieczeń i jest wpisany do rejestru agentów ubezpieczeniowych [Ustawa z dnia 22 maja 2003 r. ...].

W sprawach naruszania przez banki praktyki rynkowej Urząd Ochrony Konkurencji i Klienta (UOKiK) może wszcząć postępowanie administracyjne w sprawie nieuczciwej praktyki, natomiast gdy zostaną naruszone zbiorcze interesy klientów, prezes UOKiK na podstawie przepisów ustawy z dnia 16 lutego 2007 r. o ochronie konkurencji i konsumentów [Ustawa z dnia 16 lutego 2007 r. ...] może zastosować działania mające na celu wyeliminowanie tej praktyki z obrotu [Mrozowska 2012: 38].

Brak jasno określonych przepisów prawnych regulujących kanał bancassurance, a także problem występowania banków w podwójnej roli sprawiły, że w dniu 24 czerwca 2014 r. Komisja Nadzoru Finansowego wprowadziła uchwałę o wydaniu Rekomendacji U, dotyczącej dobrych praktyk w zakresie bancassurance. Wydanie Rekomendacji U miało na celu podniesienie standardów oferowanych produktów $\mathrm{w}$ ramach współpracy zakładów ubezpieczeń z instytucjami bankowymi. Banki zostały zobligowane do wprowadzenia regulacji zawartych w Rekomendacji U do dnia 31 marca 2015 r. [CCIFP, dostęp: 06.03.2017].

Rekomendacja U została skierowana do banków, działających według prawa polskiego, które prowadzą współpracę z zakładami ubezpieczeń, rozumianą jako pośrednictwo $\mathrm{w}$ zawieraniu umów ubezpieczenia, oferowanie ubezpieczeń na cudzy rachunek bądź w przypadku, gdy klient finansuje koszt ochrony ubezpieczeniowej, związany z ryzykiem ponoszonym przez bank [Komisja Nadzoru Finansowego 2014: 4]. Rekomendacja U zawiera 21 rekomendacji odnoszących się do następujących obszarów [Komisja Nadzoru Finansowego 2014: 3]:

- zarząd i rada nadzorcza,

- zabezpieczenie banku przed ryzykiem,

- rola banku,

- polityka rachunkowości,

- relacje z klientami,

- system kontroli wewnętrznej w zakresie bancassurance.

Brak konkretyzacji w przepisach prawnych oraz niejasność w wielu kwestiach skłoniły Komisję Nadzoru Finansowego do opracowania Rekomendacji U. Ten przepis prawny, odnoszący się do wielu spornych kwestii dotyczących bancassurance, miał za zdanie uregulowanie istotnych problemów pojawiają- 
cych się adekwatnie do rozwoju systemu ubezpieczeń sprzedawanych w instytucjach bankowych. Dosyć młoda Rekomendacja U, wprowadzona w życie od marca 2015 r., stanowi obecnie podstawę prawną działalności bancassurance.

\subsection{Znaczenie ubezpieczeń na życie w kanale bancassurance}

Według przeprowadzonego przez KNF raportu, zakłady ubezpieczeń po III kwartałach 2016 r. osiągnęły przychody na poziomie 54, 25 mld zł. W strukturze dominuje składka przypisana brutto $(75,03 \%$ przychodów ogółem) kolejne to przychody z lokat (10,12\% przychodów ogółem) oraz niezrealizowane zyski z lokat (4,61\% przychodów ogółem) [Urząd Komisji Nadzoru Finansowego 2017: 6].

Raport Polskiej Izby Ubezpieczeniowej dotyczący polskiego rynku bancassurance wskazuje, że na stan 3 kwietnia 2016 r. wysokość składki przypisanej brutto, pozyskanej w kanale bancassurance wyniosła 6,1 mld zł, co stanowiło 34,3\% składki ogółem zakładów ubezpieczeń na życie biorących udział w badaniu. Wskazuje to na spadek udziału bancassurance, ponieważ na stan 3 kwietnia 2013 r. składka pozyskana w tym kanale stanowiła 48\% składki ogółem, pozyskanej przez zakłady ubezpieczeń na życie. Jednak sama liczba ubezpieczeń na życie pozyskanych w kanale bancassurance od 2009 do 2016 r. oscylowała wokół $10 \mathrm{mln}$ sztuk, co przedstawia wykres 1 [Polska Izba Ubezpieczeń 2016: 6].

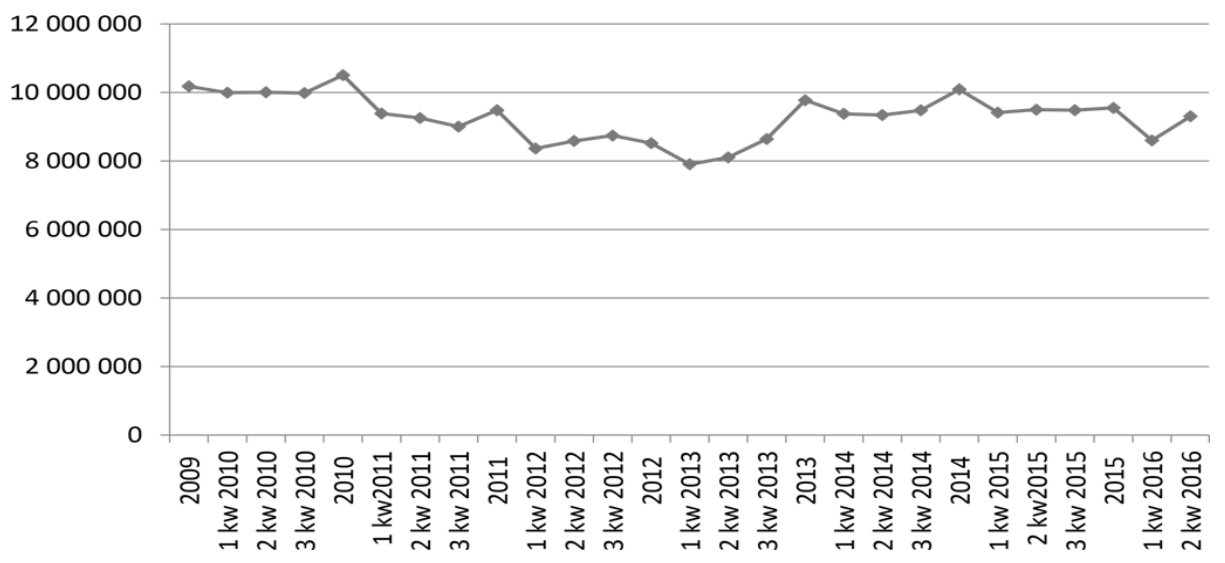

Wykres 1. Liczba ubezpieczeń pozyskanych w kanale bancassurance przez zakłady ubezpieczeń na życie w latach 2009-2016 [szt.]

Źródło: Polska Izba Ubezpieczeń [2016: 10]. 
Jak można zauważyć, sama liczba ubezpieczeń pozyskanych w kanale bancassurance nie spadła, natomiast zmalał udział składki uzyskanej w bancassurance w stosunku do ogółu.

Jak wykazuje raport, ubezpieczenia na życie stanowią większość składki uzyskanej w kanale bancassurance, składki zakładów majątkowych i osobowych na stan 3 kwietnia 2016 r. stanowiły 6,7\% składki ogółem zakładów ubezpieczeń majątkowych i osobowych, w porównaniu z rokiem 2013 jest to spadek o 1,1 punktu procentowego. Natomiast ilość ubezpieczeń oscylowała w granicach 20 tys. sztuk co przedstawia wykres 2 [Polska Izba Ubezpieczeń 2016: 26].

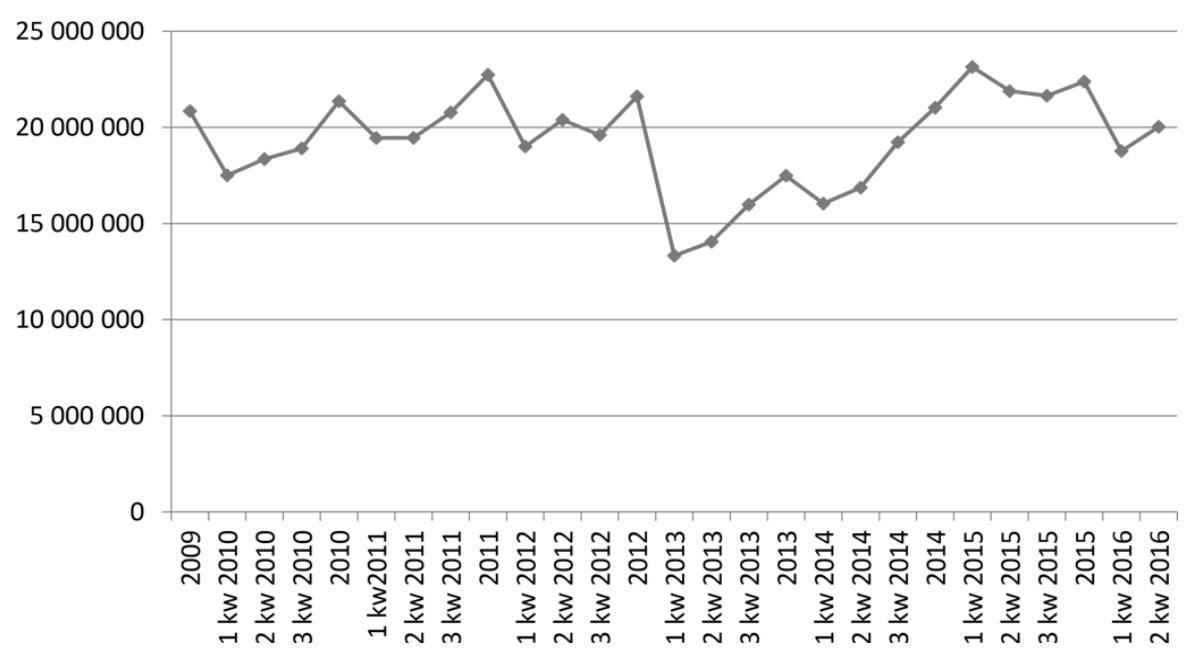

Wykres 2. Liczba ubezpieczeń pozyskanych w kanale bancassurance przez zakłady ubezpieczeń majątkowych i osobowych w latach 2009-2016 [szt.].

Źródło: Polska Izba Ubezpieczeń [2016: 37].

Podsumowując, ubezpieczenia na życie stanowią większość ubezpieczeń pozyskanych $\mathrm{w}$ kanale bancassurance, dlatego też odgrywają istotną rolę w całym systemie sprzedaży produktów ubezpieczeniowych przez banki.

\subsection{Prawa i ochrona klienta kanału bancassurance}

Rozwój kanału bancassurance na polskim rynku wykreował problem właściwej ochrony konsumenta $\mathrm{w}$ systemie ubezpieczeń udzielanych przez banki. Różnorodność udzielanych ubezpieczeń a także ich stale rosnąca ilość nie 
zawsze szły w parze z umowami ubezpieczeniowymi, zapewniającymi właściwą ochronę klienta.

Do 2015 r. za rozpatrywanie skarg na postepowanie ubezpieczycieli, prowadzących działalność ubezpieczeniową na terenie Polski odpowiedzialny był Rzecznik Ubezpieczeniowy. Od 2015 r. urząd ten przejął Rzecznik Finansowy, którym obecnie jest Aleksandra Wiktorow. W 2004 r. liczba skarg związanych z bancassurance wynosiła 39, natomiast w 2007 r. były to już 143 skargi [Orłowski, dostęp: 11.03.2017]. W związku z rosnącą liczbą skarg Rzecznik Ubezpieczonych opracował w grudniu 2007 r. raport, w którym zostały przedstawione główne problemy bancassurance w Polsce, w szczególności następujące aspekty [Rzecznik Ubezpieczonych 2007: 1-2]:

- dostarczanie klientowi odpowiedniej informacji o ochronie ubezpieczeniowej, z której korzysta,

- dobrowolność w korzystaniu z ochrony ubezpieczeniowej przez klienta,

- wpływ konsumenta na wybór ubezpieczyciela,

- dostosowanie ochrony ubezpieczeniowej do potrzeb konsumenta,

- kwestia finansowania ochrony ubezpieczeniowej,

- możliwość naruszania konkurencji na rynku przez bancassurance oraz wyrządzane w ten sposób szkody interesom konsumentów.

Część przedstawionych w raporcie problemów wywodziło się z niewłaściwego informowania konsumenta o warunkach proponowanego ubezpieczenia. Duże znaczenie miał również fakt, że pracownicy nie posiadali odpowiedniej wiedzy w zakresie ubezpieczeń oraz dotyczącej oferowanych produktów ubezpieczeniowych. W raporcie uwzględniono również problem ograniczonych praw klienta w zakresie odstąpienia od umowy ubezpieczenia, wypowiedzenia umowy a także zwrotu części składki ubezpieczeniowej z tytułu niewykorzystanej ochrony ubezpieczeniowej [Więcko 2010: 26-27].

Jednym z podstawowych celów sporządzenia raportu było zwrócenie uwagi środowiskom ubezpieczeniowym i instytucjom finansowym w Polsce na występujące nieprawidłowości oraz na potrzebę przeanalizowania zawartych w raporcie kwestii i wprowadzenie niezbędnych zmian. Po opublikowaniu raportu, Związek Banków Polskich wydał Rekomendację dotyczącą dobrych praktyk na polskim rynku bancassurance w zakresie ubezpieczeń ochronnych, powiązanych z produktami bankowymi, która ostatecznie weszła w życie 1 listopada 2009 r. Odnosiła się ona głównie do nieprawidłowości przedstawionych przez Rzecznika Ubezpieczonych w opublikowanym raporcie [Związek Banków Polskich: 2].

Po opublikowaniu raportu i Rekomendacji, właściwa ochrona klienta bancassurance nadal stanowiła istotny problem. Ilość skarg w 2011 r. osiągnęła liczbę 597, natomiast w 2014 roku było to już 1707 skarg, co stanowiło 11,1\% ogółu skarg wnoszonych do Rzecznika Ubezpieczonych. Liczbę skarg na przestrzeni 2011-2014 przedstawia tab. 1. 
Tabela 1. Liczba skarg dotycząca bancassurance w latach 2011-2014

\begin{tabular}{|c|c|c|c|}
\hline Rok & $\begin{array}{c}\text { Liczba skarg dot. } \\
\text { bancassurance }\end{array}$ & Liczba skarg ogółem & $\begin{array}{c}\text { Procentowy udział skarg } \\
\text { dot. bancassurance } \\
\text { w liczbie skarg ogółem }\end{array}$ \\
\hline 2011 & 597 & 14356 & $4,2 \%$ \\
\hline 2012 & 889 & 15273 & $5,8 \%$ \\
\hline 2013 & 1604 & 16516 & $9,7 \%$ \\
\hline 2014 & 1707 & 15429 & $11,1 \%$ \\
\hline
\end{tabular}

Źródło: Orłowski [2015].

W związku z narastającym problemem ochrony klienta w systemie ubezpieczeń udzielanych przez banki Komisja Nadzoru Finansowego w 2014 r. wydała Rekomendację U, zawierającą 21 rekomendacji. Rekomendacje od 9 do 20 dotyczą relacji z klientami, w których zawarte są następujące postanowienia [Komisja Nadzoru Finansowego 2014: 8-10]:

- banki powinny udzielać rzetelnych informacji oraz zapewniać, aby dystrybucja produktów w bancassurance nie generowała ryzyka oferowania produktów niedopasowanych do potrzeb konsumentów (rekomendacja 9);

- klient powinien mieć możliwość bezpośredniego dochodzenia roszczeń, gdy bank jest uprawniony do wypłaty świadczenia od zakładu ubezpieczeń i nie będzie chciał skorzystać z tego świadczenia. Bank powinien umożliwić konsumentowi dochodzenie roszczenia samodzielnie (rekomendacja 10);

- bank powinien podejmować działania w interesie klienta lub jego spadkobierców (rekomendacja 11);

- bank powinien przekazać konsumentowi informacje o oferowanych produktach ubezpieczeniowych, które są powiązane z produktami bankowymi aby umożliwić konsumentowi wybór produktu ubezpieczeniowego (rekomendacja 12);

- klient powinien posiadać swobodę w wyborze zakładu ubezpieczeń (rekomendacja 13);

- bank nie powinien odmawiać przyjęcia jako zabezpieczenia ekspozycji kredytowej ochrony ubezpieczeniowej, udzielanej na podstawie umowy ubezpieczenia. Bank nie może narzucić obowiązkowego przystąpienia przez klienta do umowy ubezpieczenia grupowego, w którym bank występuje jako ubezpieczający (rekomendacja 14);

- klient powinien mieć możliwość zapoznania się z postanowieniami umownymi w zakresie jego praw i obowiązków, przed zawarciem umowy ubezpieczenia lub przed wyrażeniem zgody na finansowanie składki ubezpieczeniowej. Bank powinien przedstawić klientowi adekwatne i kompletne informacje o produkcie ubezpieczeniowym, głównie w zakresie ryzyka, objętego umową 
ubezpieczeniową, informacje o warunkach ochrony ubezpieczeniowej i wyłączeń z jej zakresu, możliwych przyczyn odmowy wypłaty świadczenia oraz zasad finansowania ochrony ubezpieczeniowej (rekomendacja 15);

- bank powinien opracować procedury/zasady postępowania w przypadku umów ubezpieczeń, wobec których zakład ubezpieczeń może wystąpić z roszczeniem regresowym do klienta (rekomendacja 16);

- bank w związku z działalnością ubezpieczeniową może otrzymać od klienta zwrot kosztów związanych jedynie z zawarciem i obsługą umowy ubezpieczenia (rekomendacja 17);

- wynagrodzenia banku z tytułu produktów ubezpieczeniowych powinny być ustalane w oparciu o wysokość ponoszonych kosztów przez bank (rekomendacja 18);

- klient powinien być jednoznacznie poinformowany czy bank występuje w roli pośrednika ubezpieczeniowego czy ubezpieczającego (rekomendacja 19);

- powinna zostać zachowana należyta staranność przez banki w zakresie postanowień zawartych w umowie z zakładem ubezpieczeń (rekomendacja 20).

Istotność problemu właściwej ochrony klienta bancassurance, rozwijającego się na przestrzeni lat stała się impulsem do wprowadzenia zmian i nowych regulacji prawnych na polskim rynku. Po opublikowaniu raportu przez Rzecznika Ubezpieczonych, Związek Banków Polskich a później Komisja Nadzoru Finansowego wprowadziły rekomendacje, mające za zadanie podniesienie świadomości zaistniałych problemów oraz określenie wytycznych, które wpływałyby na wzrost ochrony i praw klienta bancassurance. Rekomendacja U, jako akt prawny stała się wyznacznikiem dla instytucji bankowych, nie tylko w kwestii relacji z klientami, ale także $\mathrm{w}$ innych obszarach działalności banków, odnoszących się do kanału bancassurance.

\section{PODSUMOWANIE}

Działalność instytucji bankowych w zakresie bancassurance, odznaczająca się szerokim wachlarzem zalet zarówno dla banków, jak i zakładów ubezpieczeń odnotowała znaczny wzrost w przeciągu ostatnich lat. Adekwatnie do liczby udzielanych ubezpieczeń pojawił się problem niewłaściwej ochrony klienta kanału bancassurance. Ogólność przepisów prawnych i niejasność w wielu kwestiach stały się przyczyną nieporozumień i sporów w zakresie praw klienta.

Duży udział ubezpieczeń na życie w ogólnej liczbie produktów ubezpieczeniowych pozyskanych w kanale bancassurance wskazuje na znaczenie tej kategorii ubezpieczeń, a co za tym idzie, ukazuje również istotność aspektu właściwej ochrony klienta, podpisującego umowę z tej grupy ubezpieczeń. 
Rosnąca liczba skarg dotycząca bancassurance, zgłaszanych do Rzecznika Ubezpieczonych, wyraźnie podkreśliła problem braku konkretnych regulacji odnoszących się do relacji z klientami, ich praw i obowiązków w zakresie podpisywanych umów. Wzrost świadomości o zaistniałych nieprawidłowościach zaowocował wprowadzeniem przez Komisję Nadzoru Finansowego Rekomendacji U, która stała się pierwszym aktem prawnym, odnoszącym się wyłącznie do działalności bancassurance. Rekomendacje od 9 do 20 uwzględniły zawarte w raporcie Rzecznika Ubezpieczonych, problemy właściwej ochrony i praw klienta.

Podsumowując, ochrona i prawa klienta w kanale bancassurance stanowi istotny aspekt $\mathrm{w}$ całym systemie udzielanych ubezpieczeń przez instytucje bankowe. Rekomendacja U, jako efekt rosnącej liczby skarg do Rzecznika Ubezpieczonych, stała się podstawowym przepisem prawnym, uwzględniającym prawa klienta bancassurance, jednocześnie odnosząc się do całego obszaru działalności tego kanału dystrybucji ubezpieczeń.

\section{BIBLIOGRAFIA}

CCIFP, Rekomendacja $U$ - dobre praktyki $w$ bancassurance, http://ccifp.pl/rekomendacja-udobre-praktyki-w-bancassurance/

Davis S. I., 2007, Bancassurance: The Lessons of Global Experience in Banking and Insurance Collaboration, Patersons, London.

Genetay N., Molyneux P., 1998, Bancassurance, Palgrave Macmillian, New York.

Handschke J., Monkiewicz J., 2010, Ubezpieczenia. Podręcznik akademicki, Poltext, Warszawa.

Komisja Nadzoru Finansowego, 2014, Rekomendacja U dotyczaca dobrych praktyk $w$ zakresie bancassurance, Warszawa, czerwiec.

Korenik D., 2006, Innowacyjne ustugi banki, WN PWN, Warszawa.

Mrozowska B., 2012, Bancassurance - regulacje prawne $i$ samoregulacja rynku, „Prawo Asekuracyjne", $\mathrm{nr} 3(72)$.

Orłowski C., Konsumenci na rynku bancassurance, „Gazeta Ubezpieczeniowa”, http://www.gu.com.pl/index.php?option=com_content \&view=article \&id=44165:konsumenci -na-rynku-bancassurance \&catid $=109 \&$ Itemid $=135$

Orłowski C., 2015, Bancassurance z punktu widzenia Rzecznika Ubezpieczonych, „Monitor Ubezpieczonych", wrzesień.

Polska Izba Ubezpieczeń, 2016, Raport PIU - Polski Rynek Bancassurance II kw. 2016, Warszawa, 27 października.

Rzecznik Ubezpieczonych, 2007, Podstawowe problemy bancassurance w Polsce, raport, Warszawa, grudzień.

Śliperski M., 2002, Bancassurance. Zwiazki bankowo-ubezpieczeniowe, Difin, Warszawa.

Urząd Komisji Nadzoru Finansowego, 2017, Raport o stanie sektora ubezpieczeń po III kwartatach, Warszawa, 19 stycznia.

Ustawa z dnia 29 sierpnia 1997 r. Prawo bankowe (tekst jedn.), Dz.U. 2016, nr 0, poz. 1988.

Ustawa z dnia 22 maja 2003 r. o pośrednictwie ubezpieczeniowym (tekst jedn.), Dz.U. 2003, nr 124, poz. 1154. 
Ustawa z dnia 16 lutego 2007 r. o ochronie konkurencji i konsumentów (tekst jedn.), Dz.U. 2017, poz. 229.

Więcko M., 2010, Działania Rzecznika Ubezpieczonych na rzecz ochrony konsumentów zawierajacych umowy ubezpieczenia w bankach, „Monitor Ubezpieczeniowy”, $\mathrm{nr} 41$, marzec.

Związek Banków Polskich, Rekomendacja dobrych praktyk na polskim rynku bancassurance $w$ zakresie ubezpieczeń ochronnych powiazanych z produktami bankowymi.

\title{
CLIENTS PROTECTION AND RIGHTS OF BANCASSURANCE IN CONTEXT OF LIFE INSURANCES
}

\begin{abstract}
Cooperation of banking institutions with insurance companies, called bancassurance, along with development has noted a significant problem of improper clients protection in the insurance's sales system. The article will show the essence of bancassurance, the importance of life insurances, the legal bases for this channel and the protection and rights of clients. The aim of the article is to present and evaluate regulations, currently applying in the polish market, relating to relations with bancassurance customers.
\end{abstract}

Keywords: bancassurance, clients protection, life insurances. 